\title{
Medical Waste: A Nobody's Responsibility After Disposal
}

\author{
Ak Mohiuddin* \\ World University of Bangladesh, Bangladesh
}

Submission: October 29, 2018; Published: November 02, 2018

*Corresponding author: Ak Mohiuddin, World University of Bangladesh, 151/8, Green Road Dhanmondi, Dhaka, Bangladesh

\section{Abstract}

Medical/hospital waste, doubt can become a potential source of poisoning. The improper disposal is a growing problem throughout the world, with a manifold effect on the cost of health care, public health and the environment. The objectives of this research are the review of current situation of medical waste generated by different Healthcare Establishments (HCE) in Dhaka city, the capital of Bangladesh, attitudes and knowledge of pharmacists/policy makers on the matter and the measures they should undertake in order to make the general public aware of the significance of proper disposal of medical waste. Thus, there is a need to initiate a concentrated effort to reduce the negative impact of waste on environment, public health and safety at health care facilities.

Keywords: Dhaka City Corporation; Health Hazard; Chemical Intoxication; Cancer; Pathogen; Healthcare Establishment

\section{Purpose of the Study}

Brief review of hospital waste disposal, their consequences and control. Healthcare providers/Policy makers have a major role play to concerned field.

Findings: Both old system and careless business mind, are responsible for this bizarre condition of hospital waste disposal. Carelessness is not the sole for this instance. A sense of poor rules and regulation is always found everywhere. Negligence is becoming a wide spread disease contaminating illiterate to well educated, all kind of people who never get bothered with unacceptable fact.

Materials and Methods: Comprehensive literature search followed by consulting healthcare professionals, Hospital, clinic, newspaper journalists, NGO workers were interviewed and asked help for necessary books, journal, newsletters. A few magazine and newspapers also observed to get necessary concern. Projections were based on hospital/clinic-based waste disposal features of urban life.

Research Limitations: Many articles and documents found in concerned area of research, but the scope of this research is on its focus point clinical hazards and burdens of Dhaka city, with a few recommendations. Still the most important aspect is covered, but fact is less amount of recent data obtained in few areas.

Practical Implication: The language of this article is too simple to understand by people with simple literacy. Pharmacists, doctors, nurses, hospital authorities, public representatives, policy makers and regulatory authorities have to acquire much from this article.

Social Implication: Any article or research is based on the think doing good for mankind, at least going ahead from the present situation, overcoming problems and measures. The article should create a guideline for the future policy makers of both government and other sectors to review the alarming situation of hospital waste management in whole Bangladesh. Again, world business is moving around Asian countries, Bangladesh will be an important business hub within next few decades. More international chain hospitals and health aid organizations will be issuing license. A mandate should be given them against waste disposal for license.

\section{Introduction}

By definition, any solid or liquid waste that is generated in the diagnosis, treatment or immunization of human beings or animals in research pertaining there to, or in the production or testing of biologically should be under consideration of medical waste. Over the last decade, the growth of the medical sector of Bangladesh along with an increase in the use of disposable medical products that contributed to the large amount of medical waste being generated. Medical waste also includes home care materials containing highly toxic metals, toxic chemicals and pathogens. As a result, several studies showed that this medical waste can present a mechanism for transmission of severe health problems as it contains highly toxic chemicals. Medical waste is going to be the next burden to a hunchback, considering pollution, population and other health hazards in urban life. The healthcare providers role in environmental health is related primarily to being alert to the conditions prevailing in the community and of working with others to adequately control any of the attendant hazards. 


\section{Results and Discussion}

\section{Waste Disposal at a Glance}

The City Corporations DCC is unable to impose rules on the public. On the institutional side, rules and regulations are not clear. Out of the waste collected, in the landfills 40-50 percent is disposed. The rest stay behind unattended on roadsides, in open drains, locally dumped in low-lying. Since Methane gas is released from municipality waste this has a harmful impact on the city's environment as well as on the global climate which is twenty-one times more damaging than carbon dioxide causing air pollution. Generally, DNCC and DSCC dispose solid wastes at two landfills in Aminbazar and Matuail. The role and responsibilities of waste generators are not clearly defined i.e., the present law does not provide penalties for illegal disposal of waste or littering. Lacks scientific approaches for problem solving and the city corporations have shortages of skilled human resources and finances. Urban planners opine that roughly $40 \%$ waste dumped in a haphazard manner included medical waste, electrical and electronic waste, construction waste and kitchen waste, etc. [1].
The accumulating waste is dumped by the residents in the city's streets, open storm water and wastewater drains or open water bodies where and whenever the collection service is inexistent or dysfunctional. In particular, slum or periphery areas are affected by such a situation. During the annual monsoon rains wastewater and storm water drains which are clogged by solid waste overflow, creating an acute sanitary and hygienic threat in low-lying slum areas particularly. Solid waste generation profile is Per Capita Waste Generation: $0.56 \mathrm{~kg} / \mathrm{cap} /$ day, Total Waste Generation DCC Area: 5000 tons/day and $70 \%-80 \%$ of the solid waste is organic [2].

\section{Different Categories of Medical Waste Found in DCC Arena}

Medical waste may contain highly toxic chemicals and can present a mechanism for transmission of diseases. The growth of the medical sector around the world over the last decade combined with an increase in the use of disposable cheap medical products of different category (Table 1) has contributed to the large amount of medical waste.

Table 1: Medical Waste of different categories.

\begin{tabular}{|c|c|}
\hline Waste Category & Description with Examples \\
\hline Infectious waste & $\begin{array}{c}\text { Pathogens may be present. E.g. excreta, laboratory cultures, tissues, materials or equipment that have been in } \\
\text { contact with infected patient. }\end{array}$ \\
\hline Pathological waste & Human tissues or fluids. E.g. blood and other body fluids, fetuses, organs, placentas, tissue etc. \\
\hline Pharmaceutical waste & Wastes containing pharmaceuticals. E.g. pharmaceuticals that are no longer needed or expired. \\
\hline Genotoxic waste & $\begin{array}{c}\text { Waste containing substances with genotoxic properties. e.g. waste containing cytotoxic drugs (often used in cancer } \\
\text { therapy); genotoxic chemicals. }\end{array}$ \\
\hline Chemical waste & $\begin{array}{l}\text { Chemical substances present in a waste. E.g. laboratory reagents, film developer; disinfectants that are expired or } \\
\text { no longer needed; solvent; Wastes from treatment (dressings, stool napkins, plaster cast etc.) }\end{array}$ \\
\hline $\begin{array}{l}\text { Wastes with high content of } \\
\text { heavy metals }\end{array}$ & Batteries, broken thermometers, blood-pressure gauges. \\
\hline Pressurized containers & Gas cylinders, aerosol cans \\
\hline Radioactive waste & $\begin{array}{l}\text { Radioactive substances present in a waste. e.g. unused liquids from radiotherapy or laboratory research (iodine } \\
\qquad 125 \text {, iodine 131), contaminate glassware, packages or absorbent paper. }\end{array}$ \\
\hline Sharps & Sharp wastes. E.g. needles, knives, blades, broken glass infusion sets, syringes, scalpels. \\
\hline
\end{tabular}

Different Types of Waste Generated by HCEs Under DCC

For a megacity like Dhaka, even low hazardous wastes generation rates can lead to the accumulation of large quantity wastes. This enormous amount of medical waste (Table 2) poses from different healthcare establishment (HCE) significant health risks to the people associated with medical waste disposal and treatment. Approximately 200 metric tons of medical wastes are generated in the city per day (Approximately $6 \%$ of total waste).

Table 2: Amount of wastes with types generated in different HCEs in Dhaka city.

\begin{tabular}{|c|c|c|c|c|c|c|c|}
\hline \multirow{2}{*}{ Color } & \multicolumn{2}{|c|}{ Type of wastes } & \multicolumn{5}{c|}{ Amount (in kg) } \\
\cline { 3 - 8 } & & DMCH & BMCH & GH** & PC** & DC** & Total \\
\hline Black & General waste (Kitchen waste, medicine box) & $2587(79.01)$ & $\begin{array}{c}563 \\
(83.65)\end{array}$ & $\begin{array}{c}729 \\
(77.31)\end{array}$ & $\begin{array}{c}286 \\
(75.26)\end{array}$ & $\begin{array}{c}143 \\
(48.97)\end{array}$ & $\begin{array}{c}4308 \\
(77.45)\end{array}$ \\
\hline Yellow & $\begin{array}{c}\text { Infectious waste (Cotton bandage, amputated body parts, } \\
\text { placenta, blood \& urine bags) }\end{array}$ & $489(14.94)$ & $59(10.57)$ & $\begin{array}{c}132 \\
(14.00)\end{array}$ & $46(12.10)$ & $57(19.52)$ & $\begin{array}{c}783 \\
(14.08)\end{array}$ \\
\hline Green & $\begin{array}{c}\text { Plastic waste (Syringe without needle, saline bags, } \\
\text { gloves) }\end{array}$ & $79(2.41)$ & $18(3.22)$ & $32(3.39)$ & $21(5.53)$ & $63(21.57)$ & $213(3.83)$ \\
\hline Red & Sharp items (needle, blade, knife, Vial-ampoule) & $36(1.10)$ & $6(1.07)$ & $12(1.27)$ & $9(2.37)$ & $6(2.06)$ & $69(1.24)$ \\
\hline
\end{tabular}




\section{International Journal of Environmental Sciences \& Natural Resources}

\begin{tabular}{|c|c|c|c|c|c|c|c|}
\hline Blue & Liquid waste & $83(2.53)$ & $27(4.83)$ & $38(4.03)$ & $18(4.74)$ & $23(7.88)$ & $189(3.40)$ \\
\hline & Total: & $3274(100 \%)$ & $\begin{array}{c}673 \\
(100 \%)\end{array}$ & $\begin{array}{c}943 \\
(100 \%)\end{array}$ & $\begin{array}{c}380 \\
(100 \%)\end{array}$ & $\begin{array}{c}292 \\
(100 \%)\end{array}$ & $\begin{array}{c}5562 \\
(100 \%)\end{array}$ \\
\hline
\end{tabular}

DMCH: Dhaka Medical College Hospital; BMCH: Bangladesh Medical College Hospital; GH: General Hospitals; PC: Private Clinics; and DC: Diagnostic Centers

\section{The Common Practice of Dumping}

While health care facilities in industrially developed countries have followed certain safety standards to minimize the health risk resulting from medical waste, the situation of risk minimization is not satisfactory at all in Bangladesh. In Bangladesh, it is reported that most of the waste handlers are from lower socio-economic condition with large family size, lower level of education and knowledge. They mostly handle the medical wastes without using necessary equipment [3]. Wastes are usually stored inside the hospital without bothering the dire consequences. The present mode of hospital wastes disposal is to dump the waste in the dustbin in or outside hospital premises and out skirts of the city for onward disposal by municipal authority [4]. The municipal authority generally dumps those hazardous alone with other wastes stream on vacant land in the name of disposal. Thus, at each stage of disposal every authority creates some loopholes in creating health problem among the hospital patients, employees, waste collectors, and people around the dumping ground

\section{Risks Associated with Careless Disposals}

Table 3: Items Disposed-off by Different disposal system.

\begin{tabular}{|c|c|c|c|c|c|}
\hline Sold & Burned & Buried & Dumped & Container/ Basin & Destroyed by acid/ Autoclave \\
\hline $\begin{array}{c}\text { Container } \\
\text { Syringe } \\
\text { Saline bag Disposable syringe } \\
\text { Bucket } \\
\text { Saline set } \\
\text { Needle } \\
\text { X-ray water } \\
\text { Plastic bottle } \\
\text { Ampoules } \\
\text { Vials }\end{array}$ & $\begin{array}{l}\text { AIDS patient's } \\
\text { clothes } \\
\text { Rabies patient's } \\
\text { clothe Paper } \\
\text { Gloves } \\
\text { Saline bag } \\
\text { Saline set } \\
\text { X-ray film } \\
\text { Needle } \\
\text { Syringe } \\
\text { Blood bag } \\
\text { Plaster of Paris } \\
\text { Apron Disposable } \\
\text { syringe } \\
\text { Plastic } \\
\text { Sputum pot } \\
\text { TB slide } \\
\text { Blood }\end{array}$ & $\begin{array}{l}\text { Common waste } \\
\text { Needle } \\
\text { Syringe } \\
\text { Blood lancets } \\
\text { Specimen } \\
\text { collection pot } \\
\text { Blood } \\
\text { Urine } \\
\text { Stool } \\
\text { Sputum } \\
\text { Saline bag } \\
\text { Damaged body } \\
\text { parts Placenta } \\
\text { Slides } \\
\text { cotton }\end{array}$ & $\begin{array}{c}\text { Cotton } \\
\text { Gauze } \\
\text { Bandage } \\
\text { Pad } \\
\text { Paper } \\
\text { Plastic } \\
\text { TB slide } \\
\text { Sputum } \\
\text { Polythene } \\
\text { Blood sample } \\
\text { Tissue paper } \\
\text { Common } \\
\text { wastes Dress- } \\
\text { ing } \\
\text { Stool } \\
\text { Urine } \\
\text { Broken tube } \\
\text { Acid } \\
\text { bottle } \\
\text { Placenta }\end{array}$ & $\begin{array}{c}\text { Tips } \\
\text { Reagent } \\
\text { Chemicals } \\
\text { Blood } \\
\text { Urine } \\
\text { Stool } \\
\text { Sputum Disposable } \\
\text { syringe Needle } \\
\text { Gloves } \\
\text { Slide } \\
\text { Broken glass }\end{array}$ & $\begin{array}{c}\text { Cotton } \\
\text { Needle } \\
\text { Syringe } \\
\text { TB slides } \\
\text { Sputum pot Vials used for sample } \\
\text { collection from the patients }\end{array}$ \\
\hline
\end{tabular}

Different researches including medical waste considered as hazardous waste, yet the main sources of hazardous/toxic waste are clinics and hospitals, whereas a small amount of hazardous waste also comes from industrial and domestic sources. There are over 600 HCEs in Dhaka city, 20\% of their wastes are infectious and hazardous [5]. Very few private HCE used to collect their in-house waste systematically. They used to segregate their sharps and infectious wastes in separate bins and send off them to the International Centre for Diarrheal Disease and Research in Bangladesh (ICDDR, B) for incineration at the rate 1.00 USD per kg of waste. The two big hospitals in Dhaka City (DMCH and $\mathrm{BMCH})$ generally were found to be disposing of their wastes into the DCC bins without segregating them. General practice with disposals detailed in Table 3. However, Medical wastes are disposed of in several places; the City Corporation's dustbin, a pit near the hospital (dig a hole), an open field/road side, or at the canal water/river. Most waste is disposed in municipal bins without any separation. Waste pickers collected and sold the waste for recycling. City cleaners took the rest of the waste at the city corporation burning area.

\section{Hazards of Medical Waste Exposure}

Health Hazards: There is a risk of injuries related to medical waste handling and carrying by waste hauler or cleaner. For example, cut injury punctuated wound, laceration, strain and sprain of the joint of limbs and backache etc. Some common cases of injuries are as follows

a) Hands cut due to handling broken glass.

b) Injured by needle and fingers permanently damaged.

c) Right hand or both legs become paralyzed due to injury by the needle.

d) Skin diseases on legs, hands and body.

e) Pus due to injury sometimes. 
f) Ulcer on legs, etc.

Hazardous medical waste poses risk to the workers handling them. They consist primarily of chemical and discarded cytotoxic drugs. The chemicals used for the testing and sampling are potentially harmful to the laboratory technicians and environment. Most of the chemicals are poured down the sink and drained out next to the clinics which have potential risk of coming in contact with people. Some of the main health risks of medical wastes are summarized below:

a) Contamination of drinking water. Possibility of leachate entering an aquifer, surface water or drinking water system.

b) During monsoon, the situation gets worse as medical, toxic chemicals and sewage waste flood Dhaka streets, contaminating dozens of neighborhoods in the process.

c) Non-biodegradable antibiotics, antineoplastic and disinfectants disposed of into sewage system may kill bacteria necessary for the treatment of sewage. Antineoplastic plashed into water courses may damage aquatic life or contaminate drinking water.

d) Burning of waste at low temperature or in open container results in release of toxic pollutants (e.g. dioxins) into the air.

e) Carcinogenic waste such as heavy metals, chemical solvents and preservatives pose serious human health risks not only to the workers but also to the general public as well.

f) Unprotected and insecure landfill may pose health risks to the scavengers and inhabitants at the vicinity.

g) The reuse of syringes by the general public represents one of the greatest public health problems in the developing world related to health care waste.

h) Worldwide, an estimated 10 to 20 million infections of Hepatitis B and C and HIV occur annually from the reuse of discarded syringe needles without prior sterilization. Sharp wastes, which include syringes and needles, have the highest disease transmission potential amongst all categories of medical waste. Almost $85 \%$ of the sharp injuries are caused between their usage and subsequent disposal. More than $20 \%$ of those who handle them encounter 'stick' injuries. Injuries from needle-stick and sharps occur frequently in developing countries, and safer disposal facilities and routine hepatitis B vaccine should be adopted.

i) A small part of the total medical waste is infectious. Still, because of ethical question and infection risks, it is a focal point of public interest. Infectious waste contains different kind of pathogens or organisms that is potential for infection or disease if it is not properly disposed. Table $4 \& 5$ shows few examples of different pathogens and disease caused by them.

Table 4: Pathogens (number per gm in solid sample and per 100ml in liquid) in hospital waste analyzed (Random) from different sources.

\begin{tabular}{|c|c|c|c|c|}
\hline $\begin{array}{c}\text { Source of } \\
\text { waste sample }\end{array}$ & Salmonella/ 100ml or gm & Shigella/ 100ml or gm & Mycobacteria/ 100ml or gm & $\begin{array}{c}\text { Amoeba/ 100ml or } \\
\text { gm }\end{array}$ \\
\hline Dustbin & $2.5 \times 10$ & $6.4 \times 10$ & $2.3 \times 10$ & $3.8 \times 10$ \\
\hline Basin water & $3.2 \times 10$ & $1.7 \times 10$ & 15 & $<1$ \\
\hline Soil & $3.1 \times 10$ & $7.2 \times 10$ & $3.4 \times 10$ & 5 \\
\hline Water & $6.8 \times 10$ & $1.2 \times 10$ & 7 & $3.7 \times 10$ \\
\hline solid & $2.5 \times 10$ & $2.0 \times 10$ & $5.6 \times 10$ & 3 \\
\hline water & $2.9 \times 10$ & $3.1 \times 10$ & 3 & $1.2 \times 10$ \\
\hline
\end{tabular}

Table 5: Pathogen and diseases caused by those pathogens.

\begin{tabular}{|c|c|c|}
\hline Pathogen & \multicolumn{1}{c|}{ Disease Potential } \\
\hline Bacterial & Tetanus, gangrene and other wound infection, anthrax, cholera, other diarrheal diseases, enteric fever, shigellosis, plague, etc. \\
\hline Viral & \multicolumn{2}{|c|}{ Various hepatitis, poliomyelitis, HIV-infections, HBV, TB, STD rabies, etc. } \\
\hline Parasitic & Amoebiasis, giardiasis, ascariasis, ankylo-mastomiasis, taeniasis, echinococcosis, malaria, leishmaniasis, filariasis, etc. \\
\hline $\begin{array}{c}\text { Fungal infec- } \\
\text { tion }\end{array}$ & Various fungal infections like candidiasis, \\
\hline
\end{tabular}

Environmental Hazards: Waste attracts scavenging animals and bats. As it ferments it gives foul odors, favors fly feeding and contaminates both water and air. During decomposition waste generates several gases, the most important among which are methane $\left(\mathrm{CH}_{4}\right)$, nitrogen $\left(\mathrm{N}_{2}\right)$ and occasionally hydrogen supplied $\left(\mathrm{H}_{2} \mathrm{~S}\right)$. If burnt, carbon dioxide $\left(\mathrm{CO}_{2}\right)$ is released. Methane and carbon dioxide are greenhouse gases and have potential greenhouse effects. The following are the environmental impacts associated with the improper disposal of medical wastes: a) Pollutants from medical waste (e.g. heavy metals and PCBs) are persistent in the environment.

b) Accumulation of toxic chemicals within soil (proximity to humans, agricultural fields, soil organism, wild life, cattle).

c) Ground water contamination decrease in water quality.

d) Bio-accumulation in organisms" fat tissue and biomagnify through the food chain. 
e) Repeated and indiscriminate application of chemicals over a long period of time has serious adverse effects on soil microbial population- reducing the rate of decomposition and generally lowering the soil fertility.

f) Pathogens lead to long term accumulation of toxic substances in the soil.

g) Windblown dusts from indiscriminate dumping also have the potential to carry hazardous particulates.

h) Public nuisance (e.g. odors, scenic view, block the walk way, aesthetics etc.)

i) Combination of both degradable and non-degradable waste increase the rate of habitat destruction due to the increasing number of sites necessary for disposal of waste.

j) Plastic bags, plastic containers, if not properly destroyed may contaminate the soil and also reduces the chance for water percolation into the soil during precipitation.

k) Open air burning does not guarantee proper incineration and releases toxic fumes (dioxin) into the atmosphere from the burning of plastics or PCBs.

\section{Guidelines and Medical Waste Management Policies in Bangladesh}

Only about $9 \%$ hospitals found following 'guidelines', of which $4.4 \%$ was reported to follow their own guidelines and about
4.5\% was found following government guidelines (e.g. manual). Though there were some manual and training handbooks for the same but due to lack of government initiatives, those were yet to be implemented to the healthcare facilities. Few NGO hospitals claimed to have their own guidelines, but they could not show or submit any written guideline document (Table 6). In fact, there is no specific legislation directly related to the handling, transportation or disposal of medical waste in Bangladesh. Officials of DGHS mentioned that some initiatives were taken for preparing few documents under the supervision of Director General of Health i.e. manual for medical waste management in Bangladesh, 2000, Pocket book of medical waste management for Nurses and Technologists, Research study-1, Strategic plan for Medical Waste Management etc. But most of them never crossed the hospital boundaries. The Ministry of Environment and Forest drafted the Hazardous Health Care Waste Management Rules 2003, which were almost similar in structure and function to that of Bio-medical Waste (Management \& Handling Rules), 1998 in India. One of the senior doctors from a renowned tertiary hospital stated, "Solid waste management (which includes solid biomedical waste) is mostly entrusted on local government bodies. The responsibility of solid waste collection and disposal lies with the City Corporations and Municipalities. The City Corporation and Pourashava Ordinance, 1977 is the only local law that consists some idea for disposal of solid waste management in Bangladesh" [6].

Table 6: Types of chemicals used in medical facilities, pharmaceuticals industries, and their uses and effects (few available examples only).

\begin{tabular}{|c|c|c|c|}
\hline Chemical & Purpose of Use & Properties & Potential effects \\
\hline Xylene & $\begin{array}{l}\text { Removal of Cedar- } \\
\text { wood oil for TB } \\
\text { slides }\end{array}$ & Toxic & $\begin{array}{c}\text { Inhalation of vapors can cause headaches, euphoria, light-headedness, dizzi- } \\
\text { ness, drowsiness, nausea, irritate skin, eyes, and lungs. }\end{array}$ \\
\hline Carbol fuchsin & $\begin{array}{l}\text { Fixing of sputum } \\
\text { slides }\end{array}$ & $\begin{array}{l}\text { Corrosive } \\
\text { Poisonous }\end{array}$ & $\begin{array}{l}\text { Readily absorbed and can cause severe burning if brought into contact with } \\
\text { skin/eyes/lungs. Inhalation results in chest pains, increased heart rate, cough- } \\
\text { ing, nose and throat irritation, convulsion, and eventually death. }\end{array}$ \\
\hline Phenol & $\begin{array}{l}\text { Disinfectant and } \\
\text { sterilizer }\end{array}$ & $\begin{array}{l}\text { Corrosive } \\
\text { Combustible } \\
\text { Poisonous }\end{array}$ & $\begin{array}{l}\text { Burning sensation to skin, eyes or lungs if contacted can seriously affect lungs } \\
\text { and respiratory system if inhaled (pulmonary edema, lung inflammation) } \\
\text { potentially fatal. Ingestion causes nausea, vomiting, GI irritation and bleeding. } \\
\text { Over exposure can lead to kidney and liver damage }\end{array}$ \\
\hline Hydrochloric Acid & $\begin{array}{l}\text { Fixing of sputum } \\
\text { slides }\end{array}$ & $\begin{array}{l}\text { Corrosive } \\
\text { Poisonous }\end{array}$ & $\begin{array}{l}\text { May cause burning sensation if brought into contact with skin/eyes Inhalation } \\
\text { causes coughing/restricts breathing and damage to upper respiratory system }\end{array}$ \\
\hline Methylene Blue & $\begin{array}{l}\text { Fixing of blood \& } \\
\text { sputum slides }\end{array}$ & & Can cause damage if brought into contact with eyes, skin, clothing. \\
\hline $\begin{array}{l}\text { Chemotherapy } \\
\text { and Anti- } \\
\text { neoplastic chemicals }\end{array}$ & Treatment & Hazardous Toxic & Carcinogenic and other health risk \\
\hline Formaldehyde & $\begin{array}{l}\text { Pathology, autopsy, } \\
\text { embalming }\end{array}$ & Hazardous Toxic & Suspected carcinogens, Eye, nose and throat irritation \\
\hline $\begin{array}{l}\text { Glutaraldehyde (fixer, } \\
\text { developer) }\end{array}$ & Photographic (X-ray) & Hazardous Toxic & Health risks \\
\hline Ethylene Oxide & Sterilizers & Hazardous Toxic & Harmful to health \\
\hline $\begin{array}{l}\text { Acid gases (e.g. } \mathrm{HCl} \\
\left.\quad \mathrm{NOx}, \mathrm{SO}_{2}\right)\end{array}$ & Laboratory & Hazardous & $\begin{array}{l}\text { Acute effects such as eye and respiratory irritation } \\
\text { May enhance the toxic effect of heavy metals }\end{array}$ \\
\hline $\begin{array}{l}\text { Chlorine made mate- } \\
\text { rial (e.g. PVC) }\end{array}$ & Laboratory & Hazardous & Creates dioxin, considered human carcinogen \\
\hline
\end{tabular}




\section{International Journal of Environmental Sciences \& Natural Resources}

\begin{tabular}{|c|c|c|c|}
\hline $\begin{array}{c}\text { PCBs (Polychlorin } \\
\text { ated biphenyls) }\end{array}$ & Medicine industries & $\begin{array}{c}\text { Hazardous } \\
\text { Toxic }\end{array}$ & $\begin{array}{c}\text { Harmful to fish and other aquatic forms of life because they interfere with } \\
\text { reproduction. PCBs produce liver ailments and skin lesions in human. In higher } \\
\text { concentration, they can damage the nervous system, and are suspected carcin- } \\
\text { ogens }\end{array}$ \\
\hline $\begin{array}{c}\text { Heavy metals } \\
\text { (mercury, arsenic, and } \\
\text { zinc, for } \\
\text { example) }\end{array}$ & $\begin{array}{c}\text { Instruments, } \\
\text { treatment, Medicine } \\
\text { industries }\end{array}$ & $\begin{array}{c}\text { Toxic } \\
\text { (neurotoxic) }\end{array}$ & $\begin{array}{c}\text { Women and children are most vulnerable, have carcinogenic, mutagenic and } \\
\text { teratogenic effects. Exposure lead to pneumonitis, bronchitis, muscle tumor, } \\
\text { irritability, gingivitis, nerve damage. In humans, these metals can produce kid- } \\
\text { ney and liver disorders, weaken the bone structure, damage the central nervous } \\
\text { system Cause blindness, and lead to death }\end{array}$ \\
\hline
\end{tabular}

\section{New Approach of Medical Waste Management}

In Bangladesh, proper medical waste management is a new phenomenon and Government of Bangladesh is trying to develop a new and modern approach to deal with the medical waste properly. City corporation officials have admitted that they have no mechanism to dispose electrical and electronic wastes while a non-government organization has been disposing medical wastes generated in the city [1]. PRISM Bangladesh (NGO) has developed a disposal facility for low cost medical waste treatment and management in Dhaka City. This project has been undertaken with the financial support of CIDA, WSP, WHO, the Embassy of Japan and UNDP with the collaboration of former Dhaka city corporation (DCC), Jessore and Savar municipalities. The DCC has allocated one acre ( 0.405 hectare) of land in Matuail, a dumpsite near the city limit for the final disposal of medical waste. It is inadequate to handle all the medical wastes of the city with the limited facilities of final disposal. They arranged training relevant personnel of different HCE for increasing awareness and proper in-house management of medical wastes also recently provided training for more than 3000 personnel in 185 HCE. According to a study performed by Prism Bangladesh Foundation, the medical waste management system of these hospitals is unsafe in every conceivable field-- collection, segregation, storage, transportation, treatment and final disposal [7].

\section{Recommendations}

The generation of medical waste in Dhaka has been increasing in quantity and variety, due to the wide acceptance of single-use disposable items. In the recent past, medical waste was often mixed with household waste and disposed of in municipal solid waste landfills. In recent times, increased concerns over improper disposal of medical waste have led to a movement to regulate the waste more systematically. Efforts have to be made for minimization and recycling of some medical wastes prior to final disposal, if not infected or contaminated. Incineration could be used in medical waste treatment until another common treatment method and steam sterilization is available in near future [8]. Therefore, toxic substances such as dioxin emissions at medical waste incinerators should be closely monitored to reduce potential risks to humans and the surrounding environment. Proper medical waste disposal system can help to control diseases and make environment free from excess carbon dioxide and methane. With the explosion of HCEs all over the country [9], it is high time also that authorities make it mandatory for such institutions to set up effluent treatment plants (ETP) so that liquid medical waste may be treated before discharge into sewerage lines that end in our water systems. Proper waste management practices must be tagged to granting of or renewal of license because public health cannot be allowed to be trifled with. To improve medical waste management system some necessary steps should be taken immediately. Some recommendations are given below:

a) Awareness of all the individuals involved in medical waste management system should be increased.

b) They should use gloves and masks during the collection and disposal of the medical waste.

c) Advanced training program for all the cleaners and waste collector should be arranged by the City

d) Corporation.

e) Proper method should be used for collection, transportation and disposal of medical waste.

f) Dumping of the edical waste should not be on open area. It should be dumped far away from the

g) community.

h) Audit section should audit the hospital and clinic frequently.

\section{Conclusion}

Lack of awareness, appropriate policy and laws, and apathy are responsible for improper management of medical waste in Dhaka City. The process of collection, segregation and disposal of medical waste is not performed according to recommended standards, and concerned people are exposed to the danger of such wastes. Safe disposal of medical waste is essential and is handled in a very professional way in many countries. The existing medical waste management system currently serves a limited number of HCE. New facilities should be established in different parts of the city or the existing facility should be expanded. Pharmacists working in HCEs should be aware of the facts and to be cognizant of the initial symptoms of disease. Again, pharmacists should become acquainted with the local community and to adapt the principles of health and medical care to the particular situations encountered. The pharmacist's continuing education requirements should include watching the pattern of clinical waste (hazardous and other waste dumps, radioactive waste) disposal and changing the emphasis toward evolving health hazards and their control [10].

\section{Acknowledgement}

It's a great gratitude and honor to be a part of healthcare research and education. Providers of all disciplines that I have 
conducted was very much helpful in discussing healthcare situations in Bangladesh, providing books, journals, newsletters and precious time. The greatest help was from my students who paid interest in my topic as class lecture and encouraged to write such article comprising clinical waste and their management related aspects of Dhaka city. Despite a great scarcity of funding this purpose from any authority, the experience was good enough to carry on research.

\section{References}

1. NEWAGE (2018) Bangladesh Sadiqur Rahman and Rashad Ahamad Pollutions leave Dhaka city in sorry state 26 .

2. Mitali Parvin and Anwara (2018) Begum Organic Solid Waste Management and the Urban Poor in Dhaka City.

3. World Bank (2002) Health Facility Waste Management Study in Bangladesh. Dhaka: World Bank.

4. Lawson A (2003) UN tackles Dhaka's medical waste. (BBC correspondent in Dhaka). http://news.bbc.co.uk/1/hi/world/south asia/3180972.stm.

This work is licensed under Creative Commons Attribution 4.0 License DOI: 10.19080/IJESNR.2018.15.555908
5. Aruna Biswas, ASM Amanullah (2011) SC Santra Medical Waste Management in the Tertiary Hospitals of Bangladesh: An Empirical Enquiry. ASA University Review, 5 (2).

6. https://www.dhakatribune.com/uncategorized/2018/02/14/ medical-chemical-radioactive-waste-whose-responsibility-anyway.

7. (2018) Dhaka Tribune Abu Hayat Mahmud Medical, chemical and radioactive waste: Whose responsibility is it anyway?

8. Nasima Akter, AMR Chowdhury, NM Kazi (1999) Hospital (Research and Evaluation Division, BRAC RESEARCH) Waste Disposal in Bangladesh with Special Reference to Dhaka City and its Environmental Evaluation ICDDR, B Special Publication No 87 February.

9. Manzurul M Hassan, Shafiul Azam Ahmed, K Anisur Rahman, Tarit Kanti Biswas (2008) Pattern of medical waste management: existing scenario in Dhaka City, Bangladesh BMC Public Health 8: 36.

10. Mohammad Zahangeer Alam, Eva Armin, Manjurul Haque, Joan Halsey, E Kayesh (2018) Abdul Qayum Air Pollutants and Their Possible Health Effects at Different Locations in Dhaka City Int J Environ Sci Nat Res 9 (4).

Your next submission with Juniper Publishers will reach you the below assets

- Quality Editorial service

- Swift Peer Review

- Reprints availability

- E-prints Service

- Manuscript Podcast for convenient understanding

- Global attainment for your research

- Manuscript accessibility in different formats

( Pdf, E-pub, Full Text, Audio)

- Unceasing customer service

Track the below URL for one-step submission https://juniperpublishers.com/online-submission.php 